\author{
Andrej Žmegač \\ Institut za povijest umjetnosti, Zagreb \\ Izvorni znanstveni rad - Original scientific paper \\ Primljen - Received 30. 6. 2020. \\ UDK 728.81(497.5Knin)“17“ \\ DOI doi.org/10.31664/ripu.2020.44/1.06
}

\title{
Modernizacija kninske tvrđave u 18. stoljeću
}

\begin{abstract}
Sažetak
U radu se tumače modernizacijski zahvati na kninskoj utvrdi nakon što su je 1688. zauzele mletačke snage. Taj proces prati se na temelju više dosad neiskorištenih tlocrta, medu kojima su najvažniji oni iz Muzeja Correr u Veneciji. Objavljen je i dosad nepoznat projekt kninske tvrđave iz Stuttgarta. Pisani pak izvori potječu iz dobro poznatih fondova u Veneciji, ali se važnom pokazala i ostavština inženjera Camozzinija,
\end{abstract}

upravitelja kninskih radova, sačuvana u Hvaru. Na temelju rečene građe autor nastoji odrediti udio inženjera Antuna Jančića u glavnoj modernizacijskoj kampanji od 1710. do 1713. godine. S obzirom na važnost kninske tvrđave sve do kraja Mletačke Republike, u radu se navode i komentari nekih njezinih vojnih stručnjaka, poput generala Spara (1731.) i Graemea (1758.).

Ključne riječi: tvrđava, bastion, Mletačka Republika, Knin, Antun Jančić

Uz bogatu i istaknutu povijest kninske utvrde, koja se veže uz rani srednji vijek i razdoblje hrvatske države, ipak su tek kasnija stoljeća na njoj ostavila do danas postojeće građevne strukture. Nešto zidina potječe iz kasnoga srednjeg vijeka, ponešto je i turskih struktura, no najprisutniji je sloj koji je uspostavila Mletačka Republika u 18. stoljeću. To je svakako rezultat interesa što ga je Serenissima pokazala za ovu tvrđavu, to jest namjere da čvrsto nadzire i ovu točku duboko u dalmatinskom zaleđu. ${ }^{1}$

Od 1522. Knin je bio pod osmanskom vlašću, a mletačke snage nakratko su ga zauzele 1648. godine, tijekom Kandijskog rata. ${ }^{2}$ Definitivno je onda pripao Veneciji u doba Morejskog rata. ${ }^{3}$ Svako razmatranje o modernim strukturama u sklopu kninske tvrđave mora početi od snimka koji je izradio Orazio Alberghetti, neposredno po tom drugom zauzimanju Knina, 1688. godine. ${ }^{4}$ Riječ je o listu s dvama crtežima: pogledom na utvrdu te tlocrtom s prijedlogom bastionskog pojasa oko kninskog naselja. Ti su crteži dragocjen dokument o stanju utvrde potkraj turske vlasti, a prije bilo kakvih mletačkih zahvata. Usmjerit ćemo pozornost na tzv. drugi (glavni, srednji) obzid, kojemu na jugu vidimo šesterokutni istak na mjestu kasnijega bastiona Vendramin. Uz mjesto pak glavnog ulaza (»L«) stajala je prije četverokutna kula, no nakon mletačkog osvajanja ta je cijela zona bila razrušena (u legendi: brecche). Naposljetku, pogledajmo i sjeverni završetak utvrde: tu se može uočiti kulu označenu s $\mathrm{O}$ «(torre quadra terrapienata), a pred njom i malena zaštićena vrata (picciola porta). Sudeći prema oba crteža, prostor unutar obzida, sve do stjenovite strmine, bio je popunjen povelikim brojem kuća $(s l .1,2){ }^{5}$

Već Alberghetti je, dakle, izradio projekt za pojačanje Knina, doduše obuhvaćajući cijelo naselje u nizini, a uglavnom bez intervencije u vršnom dijelu. I u sljedećim godinama se očito nižu projekti, kao primjerice 1693. godine: tom su prilikom prijedloge dali inženjeri Muttoni i Bucò, a boljim je smatran onaj Muttonijev. ${ }^{6}$ No crtež nije sačuvan te nam projekt nije pobliže poznat. Godine 1699. potom se Kninom bavio inženjer Giuseppe D’Andre, izvodeći ondje manje zahvate, ${ }^{7}$ a u idućem će desetljeću, kako ćemo vidjeti, za tvrđavu raditi i opsežnije projekte.

Neke važne pojedinosti doznajemo onda iz završnoga izvješća dalmatinskoga providura Alvisea Moceniga iz 1702. godine. ${ }^{8}$ Piše da je kninska utvrda u slabom stanju, ali je unatoč tome važna jer su joj blizu kako austrijski, tako i turski teritorij. ${ }^{9}$ Mocenigo navodi da je nedostatak vode stajao Turke gubitka utvrde, pa je on, uz podizanje nekih vojarna i skladišta, dao popraviti i cisterne. No to nije bilo mnogo s obzirom na potrebe. U istom dokumentu donesen je i podatak o D’Andreu koji je pripremao projekt za Knin. 

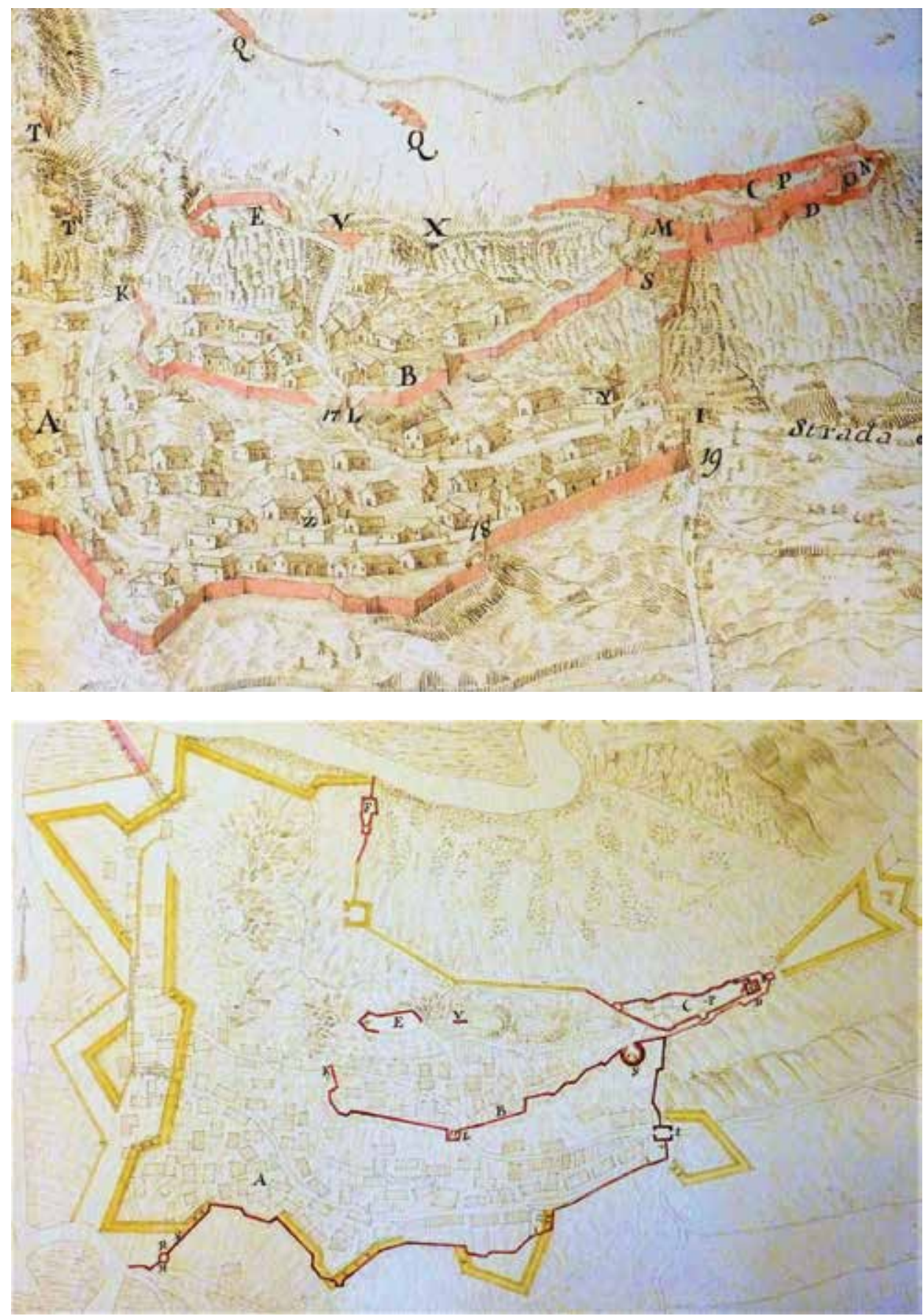

1. Kninska utvrda, 1688., detalj (O. Alberghetti; Biblioteca Nazionale Marciana, Venecija) Knin Fortress, 1688, detail (O. Alberghetti; Biblioteca Nazionale Marciana, Venice)

2. Kninska utvrda s projektom bastionske utvrde oko naselja, 1688., detalj (O. Alberghetti; Biblioteca Nazionale Marciana, Venecija)

Knin Fortress with a project for bastion fortification around the settlement, 1688, detail (O. Alberghetti; Biblioteca Nazionale Marciana, Venice)

Iz prvoga desetljeća potječe i anonimni dokument o radovima koji se preporučuju za dalmatinske utvrde. ${ }^{10}$ $\mathrm{Za}$ Knin je zapisana preporuka da se poravnaju grebeni između Kaštela i Korlata, ${ }^{11}$ kako bi se ti dijelovi mogli međusobno braniti. Valjalo je izgraditi i nove barutane i cisterne. Napokon, jedan od ulaza (porta Cornara, u tzv. donjem obzidu) trebalo je premjestiti u sredinu kurtine, te podići manji bastion radi flankiranja. Iscrpno se potom na Knin osvrće također anoniman opis Dalmacije iz 1708. godine. ${ }^{12} \mathrm{Ne}$ propušta se registrirati da je mnogo toga učinjeno, poput vojarna, skladišta, cisterna, ${ }^{13}$ no isti tekst upozorava kako je unatoč tomu utvrda još uvijek slaba. ${ }^{14}$ $\mathrm{U}$ više navrata navedena je njezina nesuvremenost jer su joj zidine d'antica struttura. 


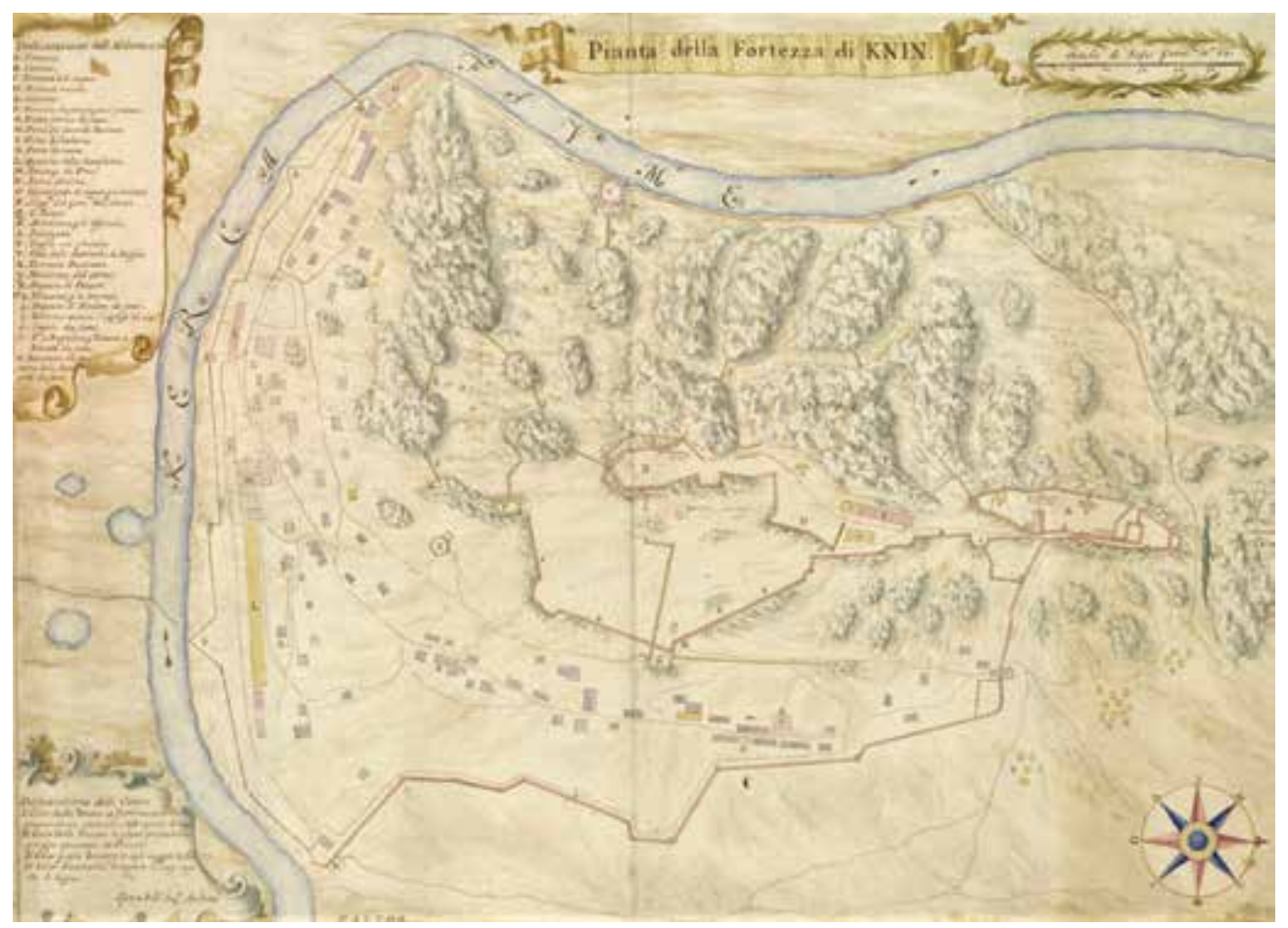

3. Projekt dogradnje, 1708. (G. D’Andre; Archivio di Stato, Venecija) Extension project, 1708 (G. D'Andre; Archivio di Stato, Venice)

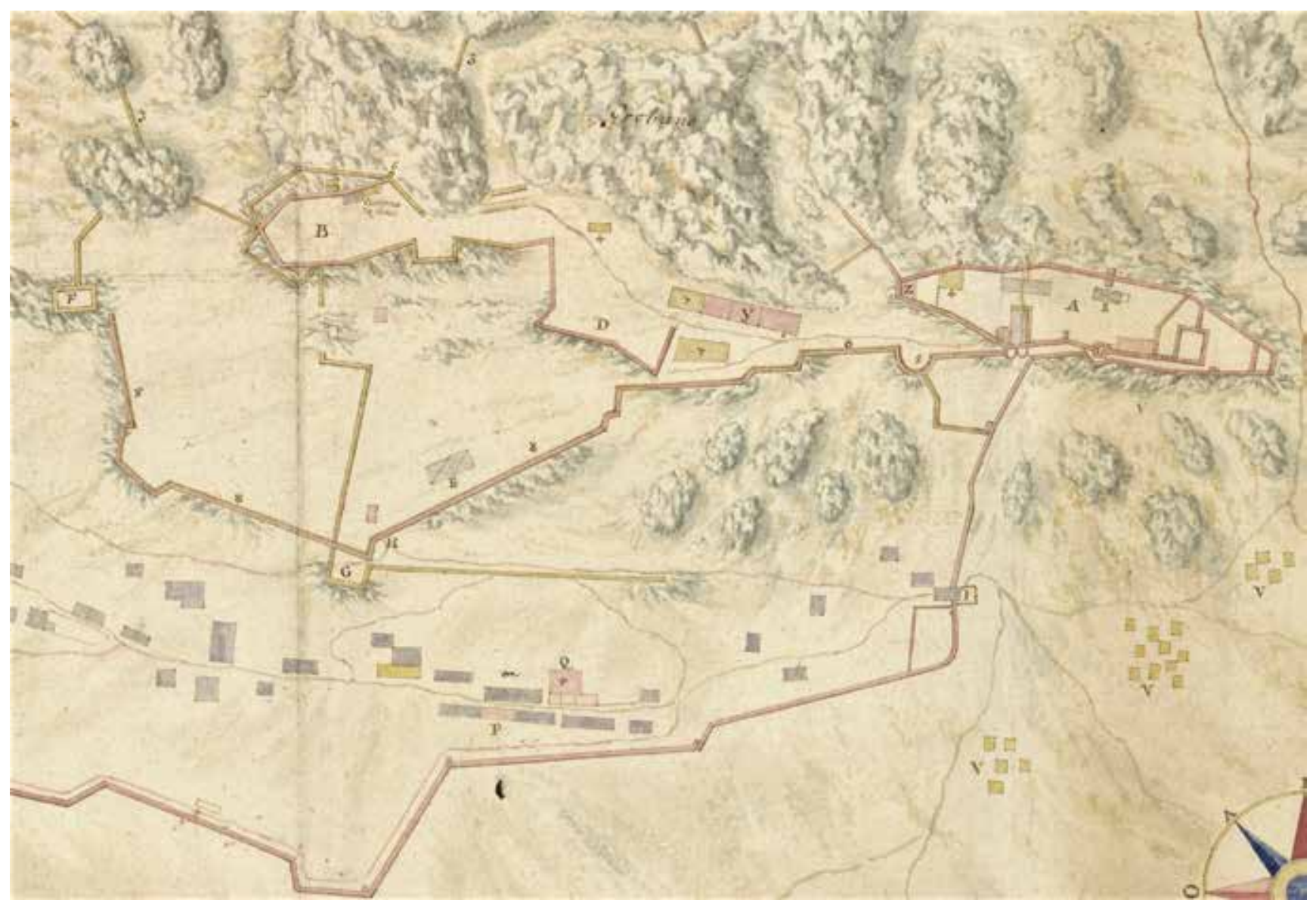

3a. Projekt dogradnje, 1708., detalj

Extension project, 1708, detail 


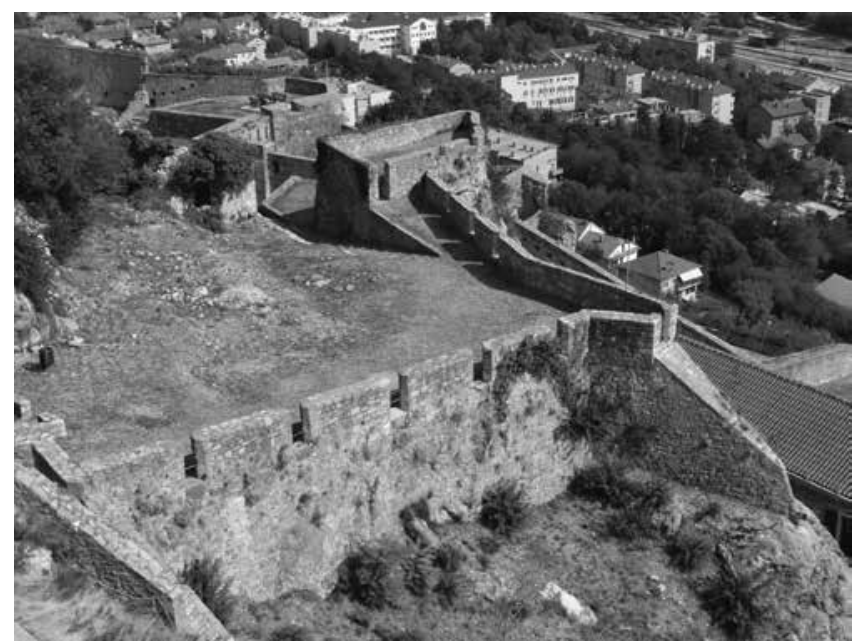

4. Položaj Candia nuova

Posto Candia nuova

Po svemu sudeći, faza intenzivne pripreme za modernizaciju kninske utvrde počinje 1708. godine. Iz toga doba postoji bilješka Vincenza Vendramina, generalnog providura Dalmacije, o tome kako je dobio nalog za izradu projekta za Knin. ${ }^{15}$ Projekt je onda pripremio spomenuti inženjer D’Andre te ga popratio opisom, tj. komentarom datiranim krajem iste godine. ${ }^{16}$ D’Andreov tlocrt je sačuvan, ${ }^{17}$ a najprije valja zapaziti kako neobično sliči Justerovu odnosno Binardovu snimku, nastalima u isto doba; koji je među njima »izvornik «, nije na ovome mjestu bitno. U svome je nacrtu D’Andre predložene strukture označio zelenkastom bojom, ${ }^{18}$ jasno ih odvojivši od crveno označenih postojećih zidova (sl. 3, 3a). Prije svega, može se uočiti da je zabilježio postojanje jedne strukture koja nije bila vidljiva na Alberghettijevu snimku, pa je očito da je uspostavljena od 1688. do 1708. godine; riječ je o bedemu označenom u legendi s Ritirata nuova, a u kasnijim prikazima Knina nosit će naslov Candia nuova. Dakle, i njezin naziv pokazuje da je bila novonastala. To je struktura prepoznatljiva šiljatoga tlocrtnog oblika, sjeverozapadno od glavnog ulaza. Drugo što valja zapaziti drukčiji je tlocrtni oblik onoga šesterokutnog istaka iz Alberghettijeva prikaza, u južnome dijelu obzida, na mjestu budućega bastiona Vendramin. Sada je on podjednako plitak, ali formiran na način bastiona kao peterokut, pa postoji mogućnost da se i ta promjena odigrala u naznačenom razdoblju. No glavna je novina D’Andreov prijedlog dugoga zida što je trebao štititi prilaz koji se uspinje iz pravca Loredanovih vrata. Pred postojećim ulazom trebala je (ponovno) biti uspostavljena platforma (u legendi: Piatta forma da farsi), a odatle je zid bio poprijeko usmjeren preko platoa, sve do stjenovita podnožja Korlata. Opis te osebujne strukture može se identificirati u D’Andreovu tekstu. ${ }^{19} \mathrm{Za}$ razliku od ove zone, drukčijom bojom nisu označene nikakve intervencije na sjevernom završetku utvrde. Pa ipak, jedna dionica D’Andreova opisa kao da se odnosi na tamošnju situaciju ${ }^{20}$ gdje je zastarjela struktura utvrda bila nedovoljno zaštićena jarkom od nasuprotnog platoa.

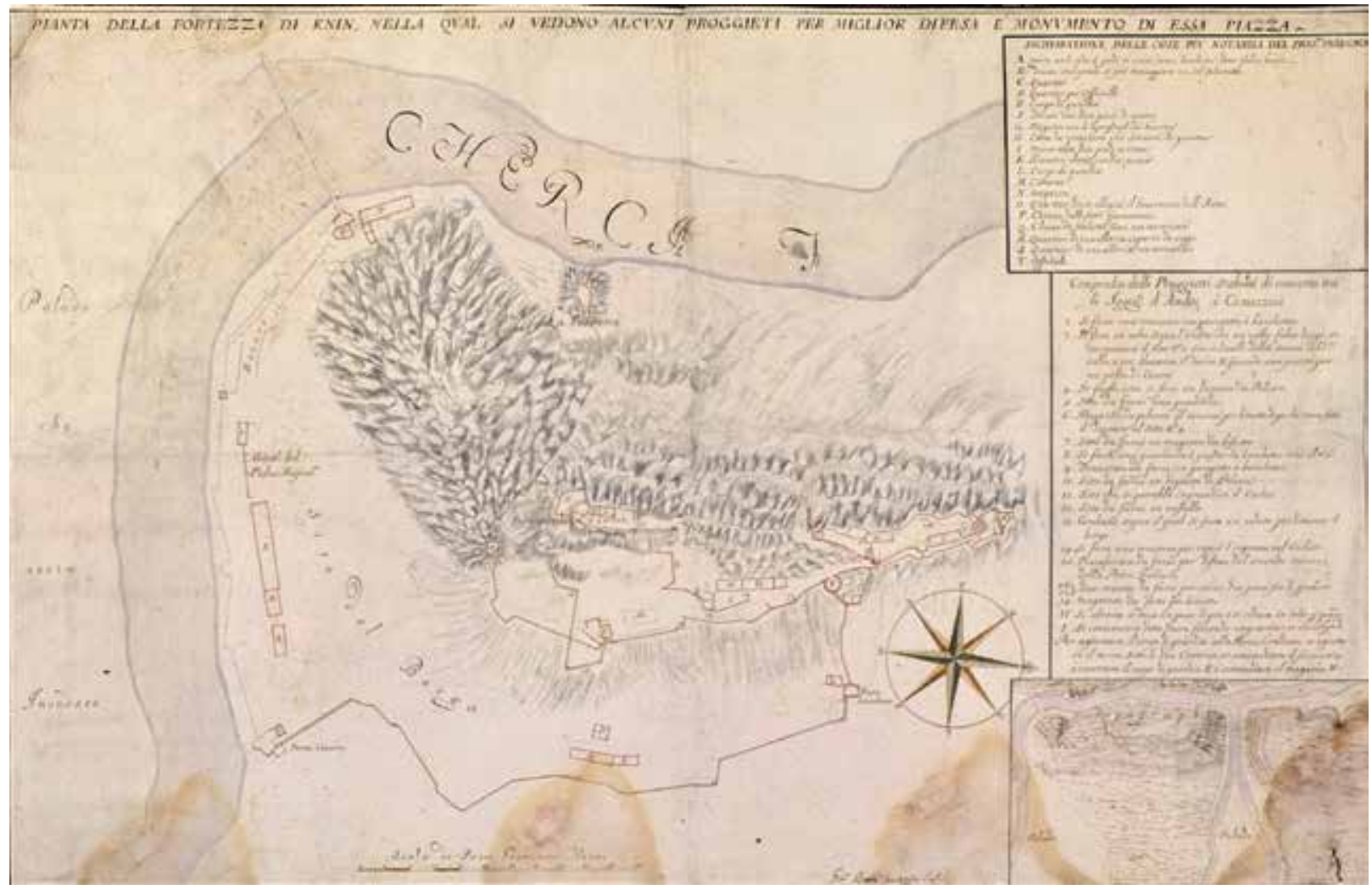

5. Projekt dogradnje, oko 1708. (G. D’Andre / G. B. Camozzini; Biblioteca del Museo Correr, Venecija, 2020 @ Archivio Fotografico - Fondazione Musei Civici di Venezia)

Extension project, around 1708 (G. D’Andre / G. B. Camozzini; 2020 ○ Archivio Fotografico - Fondazione Musei Civici di Venezia) 


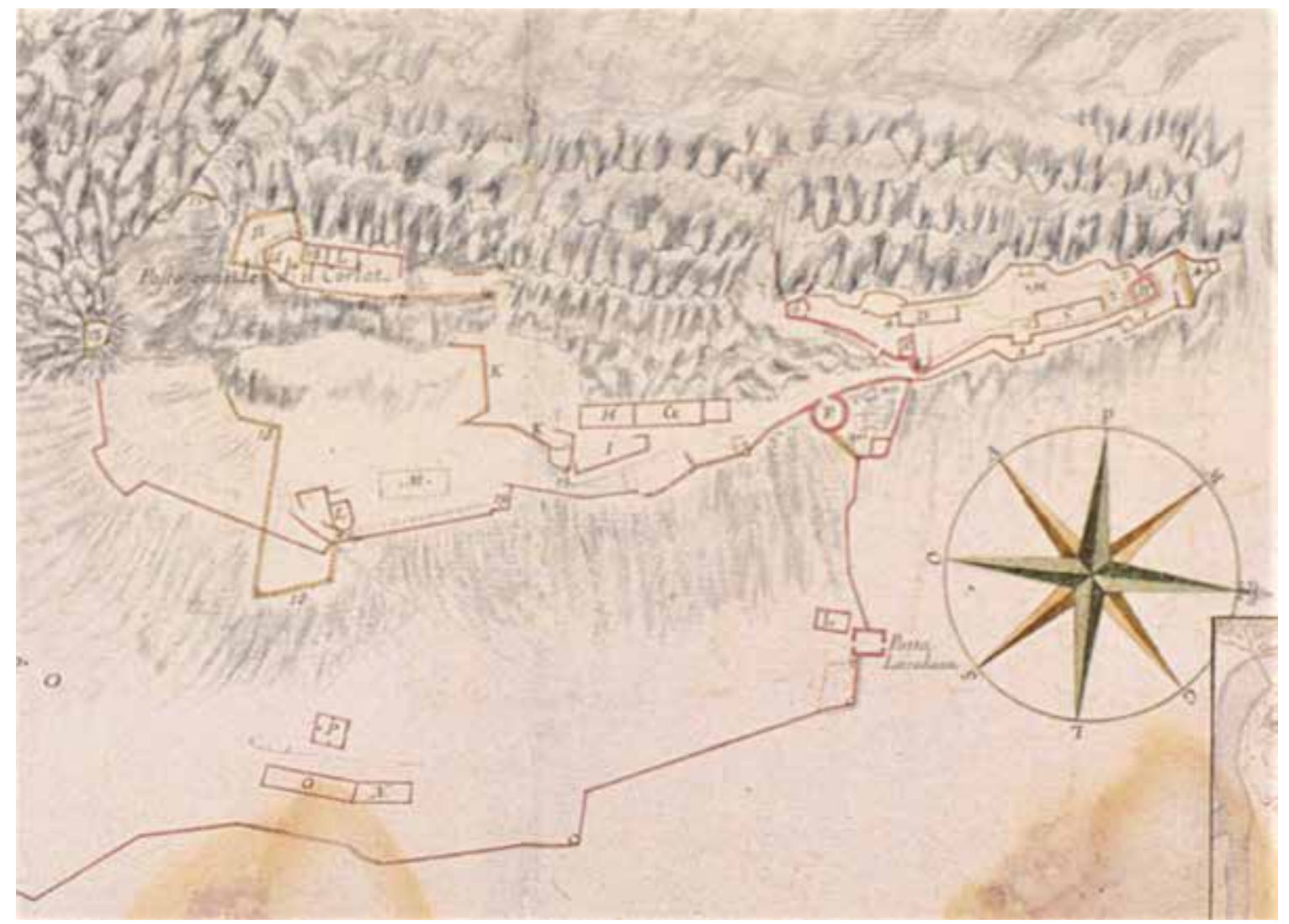

5a. Projekt dogradnje, oko 1708., detalj

Extension project, around 1708, detail

Sljedeći projekt ${ }^{21}$ morao je nastati ubrzo nakon toga, gotovo istodobno, a predstavlja varijantu opisanog D'Andreova prijedloga. Sada je riječ - kako legenda navodi - o usuglašenom zajedničkom rješenju D’Andreovu i Camozzinijevu. ${ }^{22}$ Sada je platforma uz glavni ulaz znatno veća te tlocrtno ima oblik polubastiona. Smisao joj je, kao što pokazuje legenda, ${ }^{23} \mathrm{da}$ štiti niža Loredanova vrata te drugi obzid, u čijem se sastavu i nalazi. Nalik prethodnom projektu, od platforme vodi poprečni bedem do podnožja Korlata. No posebnu pozornost moramo usmjeriti na sjeverni završetak, jer dva inženjera sada nedvojbeno ondje pripremaju preuređivanje postojećih struktura. Ponovno u legendi čitamo kako su zamislili nadsvođenje jednoga prostora, potom nasipavanje zemljom drugoga, te napokon snižavanje tamošnje kule..$^{24}$ Bila je zapravo riječ o ujednačavanju visine različitih prostora kako bi se stvorila nova platforma za postavljanje većeg broja topova; na staroj je srednjovjekovnoj kuli, navodi također legenda, mogao biti smješten tek jedan top, ${ }^{25}$ a nova bi ih platforma mogla ponijeti tri (sl. 5, 5a).

\section{Jančićev zahvat}

Sljedeća, jedna od najznatnijih faza u razvoju kninske utvrde vezana je uz djelovanje inženjera i generala Antuna Jančića. Boravio je u Dalmaciji, kako se čini, od kraja listopada 1709. do početka siječnja 1710 . godine. ${ }^{26}$ Prvenstvena mu je zadaća bila razmotriti na licu mjesta projekt što ga je za Knin bio pripremio D’Andre, te potom predložiti zahvate za bolje osiguravanje te važne utvrde. ${ }^{27} \mathrm{U}$ svome opsežnom izvješću Jančić piše kako je obišao svaki kninski obzid koristeći se pritom D’Andreovim snimkom, ne nalazeći pritom za njega pohvalne riječi. Utvrdio je pogreške kako u snimku, tako i u projektu, naposljetku i u proračunu, pa je morao uz pomoć satnika Faleta i inženjera Camozzinija pristupiti izradi točnijeg snimka, nužnoga i za novi projekt. ${ }^{28} \mathrm{O}$ Jančićevu projektu i zahvatima koji su potom uslijedili već smo pisali, ${ }^{29}$ no $\mathrm{s}$ obzirom da je posrijedi najvažnija intervencija na kninskoj tvrđavi u 18. stoljeću, valja joj se ponovno i pobliže posvetiti. Temeljni su nam dokumenti pritom spomenuto Jančićevo izvješće te tlocrt s prikazom njegova projekta. ${ }^{30}$ Jančićeve se zamisli mogu dobro pratiti povezivanjem dvaju dokumenata, pa ipak vidimo da se tekst ne referira baš na ovaj tlocrt, jer se oznake u njima (slova i brojke) ne poklapaju. To znači da je postojao još neki pripadajući tlocrt, no u nedostatku toga dokumenta preostaje da se koristimo ovim postojećim; svakako je on vremenski vrlo blizak nastanku teksta te nesumnjivo tumači istu zamisao (sl. 7, 7a).

Jančić je svoj prijedlog izložio u dvama "projektima«, jedan esencijalni i primarni, te drugi koji bi se mogao nazvati dopunskim. Prvim je obuhvatio gornje obzide tvrđave (Kaštel, Korlat i drugi obzid), a drugim donji obzid, tj. utvrde naselja 


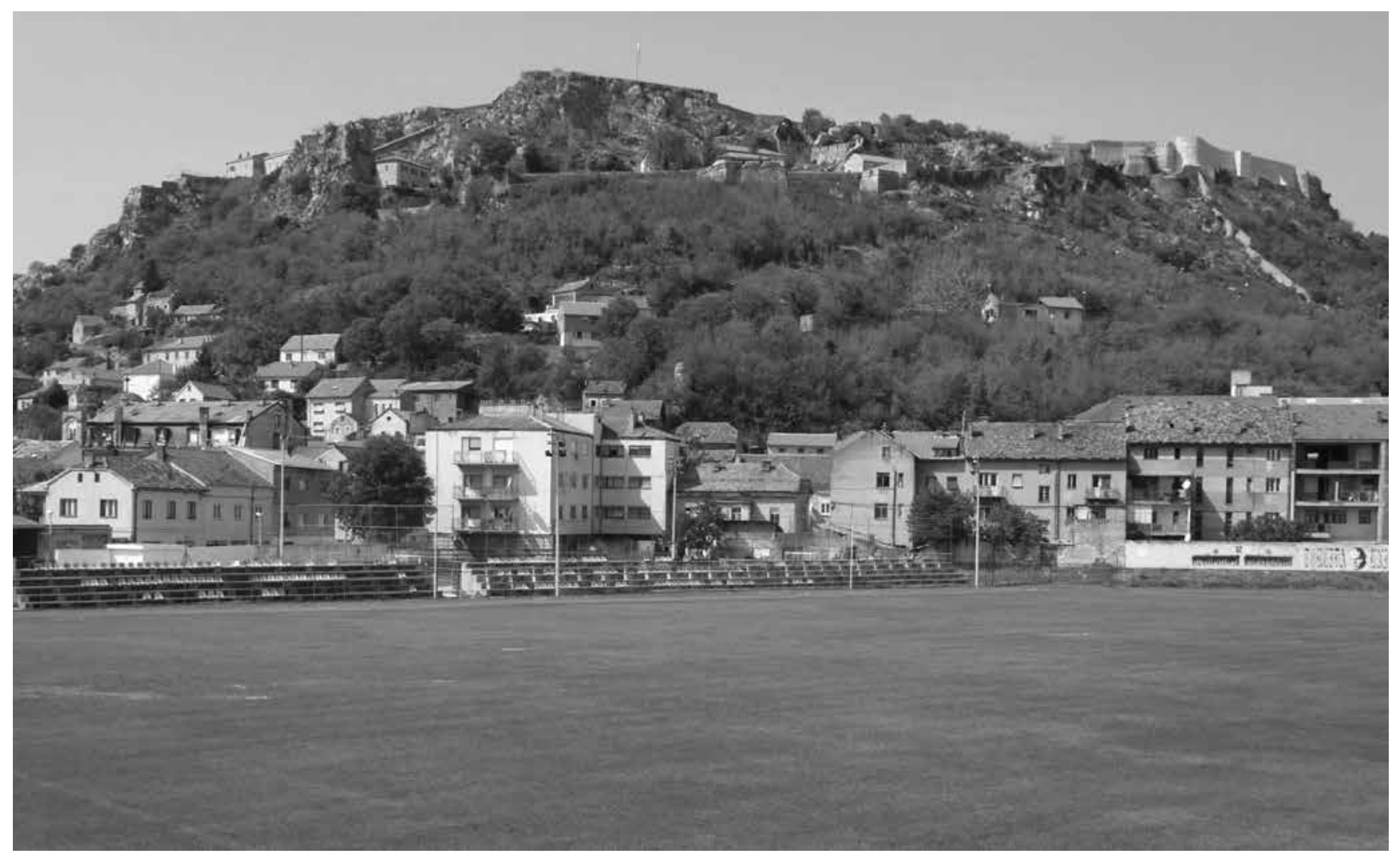

6. Kninska tvrđava s istoka

Knin Fortress from the east

te uzvisine Promine s druge strane Krke. Zanimljiva je i neočekivana Jančićeva formulacija da će u dvama projektima izložiti » univerzalnu ideju utvrđivanja «, ${ }^{31}$ a tu misao ponavlja i na drugome mjestu u izvješću. Ostaje nejasno je li mislio na sveukupnost mjera kako bi bila postignuta sigurnost, poput iskorištavanja i morfoloških danosti lokacije, ili na primjenu suvremenih fortifikacijskih postupaka, dakle bastionskih struktura, no formulaciju se danas čita kao nešto uzvišeno u opisu njegova projekta.

U sklopu primarnog projekta Jančić predlaže podizanje vojarni za 250 vojnika, tri spremišta, kuću za vojnog upravitelja (governatore dellarmi) te dvije barutane otporne na bombe. ${ }^{32}$ Navodi potom različite zidove te obrambene položaje (alloggiamenti), i to na zapadnoj strani, na obronku prema Krki. Samo dio tih prijedloga doživio je izvedbu - primjerice nisu podignute barutane na mjestima i u oblicima kako ih je Jančić bio zamislio. S druge strane, od njegovih zamisli, a kojih nije bilo u prethodnom projektu D’Andre/Camozzini, izvedena je struktura na hrptu uzvisine, kao prva poveznica između dotad razdvojenih Kaštela i Korlata. Taj bedem naveden je i u legendi kao Traversa da fare perfar una battaria con parapetto, drugim riječima bio je zamišljen kao osnova za uređivanje nove baterije, što je uskoro i bilo ostvareno kao Položaj sv. Cecilije. Potom je nesumnjivo njegova zamisao južni sklop Belveder, koji se prvi put pojavljuje u prikazu njegova projekta. Izvedbu je doživjelo i Jančićevo rješenje falsabrage, predbedema nad prilazom što vodi od Loredanovih vrata prema ulazu u drugi obzid.
Sastavljajući svoj izvještaj, Jančić identificira dvije osjetljive točke kninskoga kompleksa i drži da ondje treba fortifikacijski intervenirati: na sjevernom završetku Kaštela, ondje gdje mu prema sjeveru leži opasan plato, u ono doba još nedostatno odvojen jarkom od tvrđave. $S$ tog su platoa, uostalom, i Mlečani bili 1688. godine bombardirali tvrđavu u turskom posjedu. Druga je osjetljiva zona bila na jugoistoku, podno Korlata. ${ }^{33}$ I ovaj su pravac Mlečani bili koristili za napad, znajući dakle dobro njegove slabosti u ono doba: prvo su topovima bili otvorili prolaz u donjem, prvom obzidu, a potom načinili brešu i u drugom obzidu, razrušivši zonu ulaza, ${ }^{34}$ kako smo to vidjeli u Alberghettijevu crtežu. Jančićevo rješenje značilo je zbog toga formiranje bastionske strukture s predbedemom na tome mjestu, i to tako da postojeći zid bude djelimice iskorišten kao predbedem, a da novi bedem bude uspostavljen na uvučenijoj liniji. Kad su posrijedi predbedemi, Jančić im smisao tumači time da olakšavaju nadzor padine pod sobom. Bastioni pak ostaju lišeni predbedema, no projektant navodi kako oni stoje na stijenama znatne visine, što bi značilo da su razmjerno sigurni. Tko bi ih želio napasti, dodaje Jančić, morao bi najprije prevladati predbedem i tako se izložiti vatri s bastiona. ${ }^{35}$ Predbedemi u tlocrtu imaju V-oblik, najjednostavniji oblik tenalje (tzv. kliješta). Spomenimo da je zanimljiv obrat učinjen u legendi Jančićeva tlocrta, gdje nije - očekivano - navedeno kako su predbedemi u obliku tenalje, već obratno: tenaglie in forma di false braghe. Južniji bastion ponio je ime generalnog pro- 


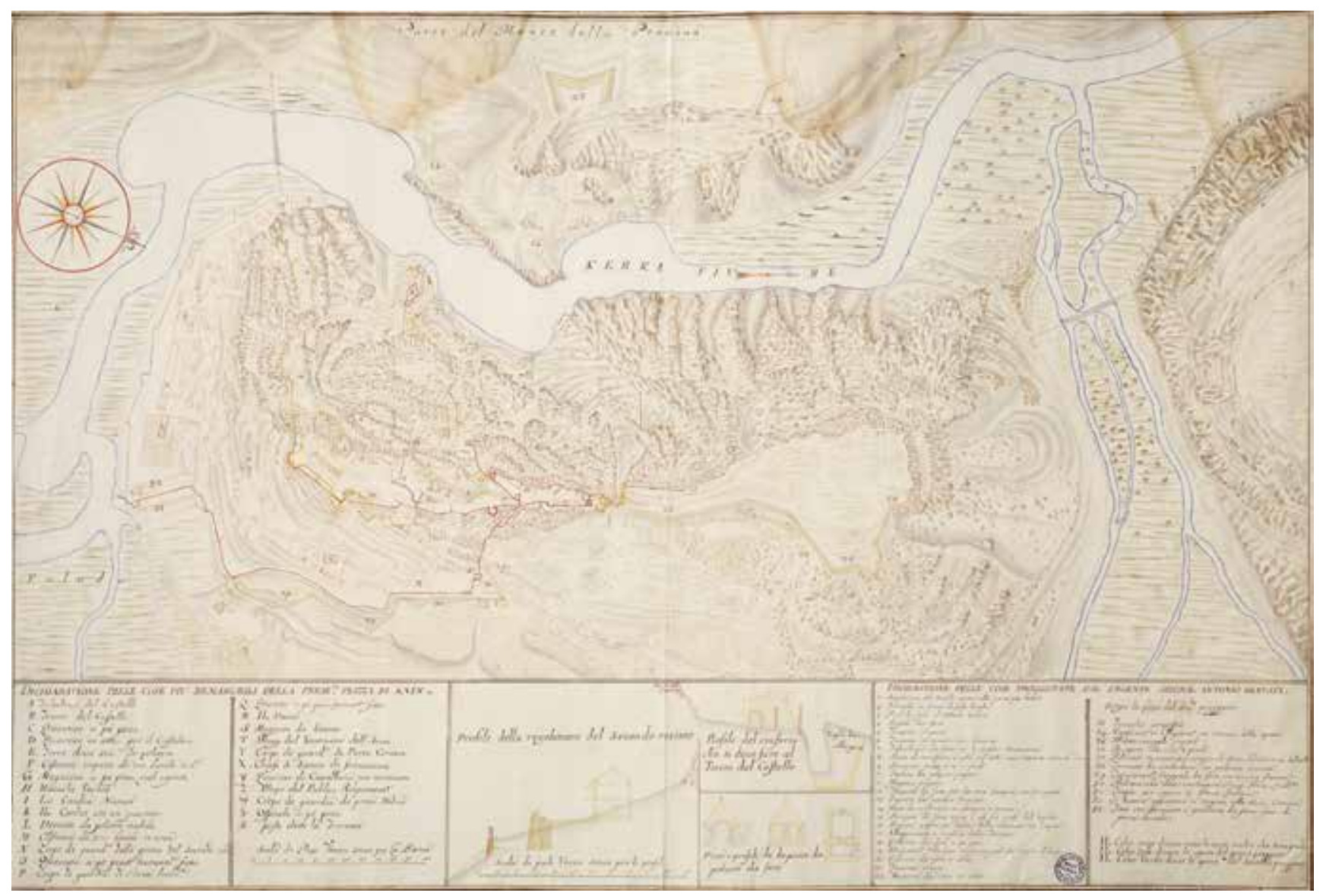

7. Jančićev projekt modernizacije, 1710. (Biblioteca del Museo Correr, Venecija, 2020 @ Archivio Fotografico - Fondazione Musei Civici di Venezia)

Jančićs modernization project, 1710 (2020 @ Archivio Fotografico - Fondazione Musei Civici di Venezia)

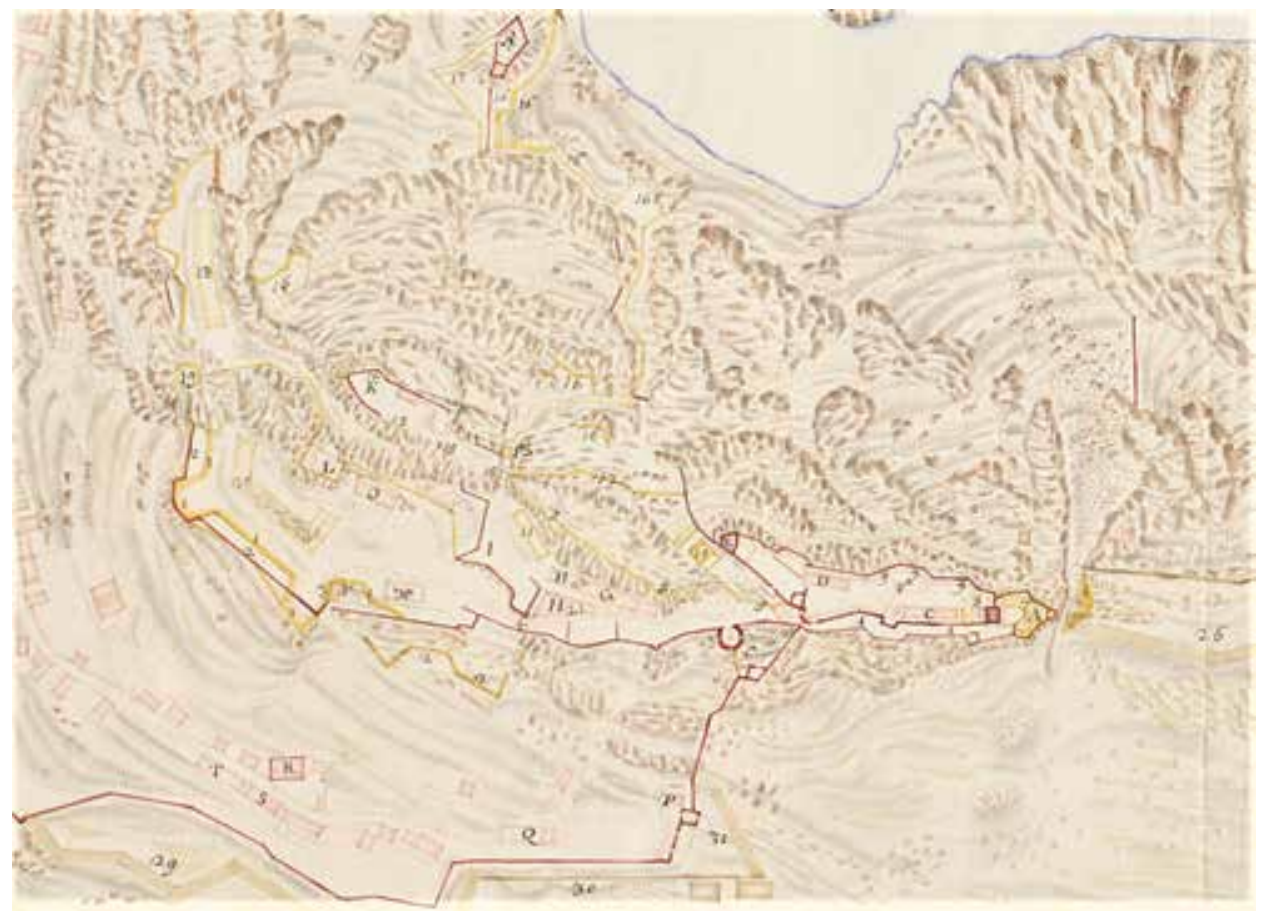

7a. Jančićev projekt modernizacije, 1710., detalj Jančićs modernization project, 1710, detail 
vidura Vendramina, a glavni ulazni providura Pisanija, u čije doba i pada izgradnja te strukture (sl. 8).

Opisani zahvat u drugome obzidu, na jugoistoku, najdojmljiviji je i svakako neosporiv trag Jančićeve aktivnosti $u$ Kninu. Nešto je manje jasna situacija sa sjevernim završetkom cijele tvrđave, onim mjestom koje je Jančić u svome izvješću označio drugom točkom kojoj valja posvetiti punu pozornost. Čini se da kako opis projekta, tako i njemu blizak tlocrt u bitnome ponavljaju ono rješenje koje smo upoznali u projektu D’Andre/Camozzini. Jančić dakle predviđa preuređivanje predbedema na samome sjevernom vrhu tako da može izdržati topovski napad s nasuprotnog platoa, odnosno da može ponijeti dva-tri topa. On je predložio gradnju svoda koji bi pružio posadi zaklon od bombi, projektila iz mužara te odbijenoga kamenja s kule, a poslužio bi i kao spremište za stvari i hranu. Kulu bi pak, očekivano, trebalo sniziti do razine susjednoga dijela, te proširiti bedem tako da bude položajem za postav dvaju topova. ${ }^{36}$ Takva koncepcija, opisana tekstom te prikazana tlocrtom, ne odgovara, međutim, onoj impozantnoj građevini koju danas zatječemo u sklopu kninskoga Kaštela. Moglo bi se stoga zaključiti da ona potječe iz nekoga kasnijeg zahvata, posve odvojenoga od kampanje koja je prema Jančićevu projektu bila započeta 1710. odnosno 1711 . godine.

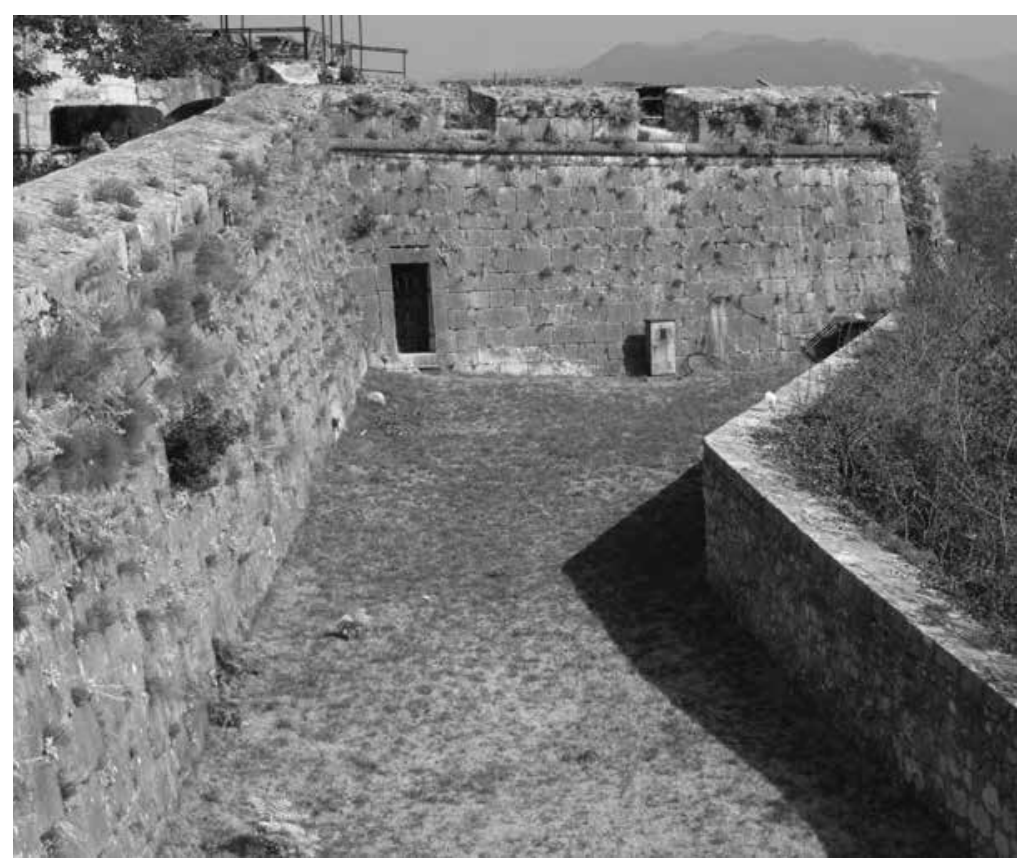

8. Bastion Pisani

Pisani bastion

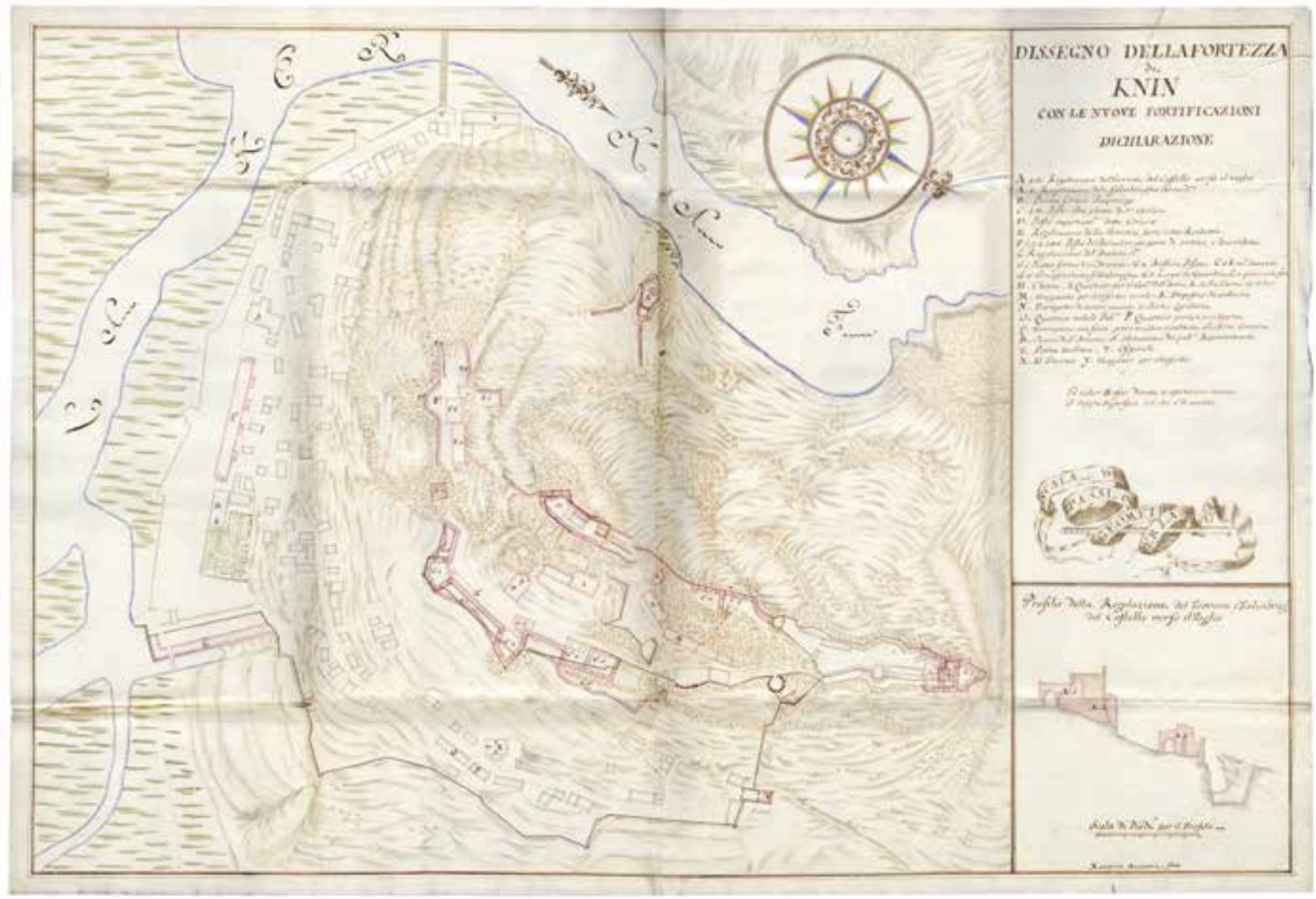

9. Stare i nove strukture na tvrđavi (X. Avesani; Biblioteca del Museo Correr, Venecija, 2020 @ Archivio Fotografico - Fondazione Musei Civici di Venezia)

Old and new structures at the fortress (X. Avesani; 2020 @Archivio Fotografico - Fondazione Musei Civici di Venezia) 


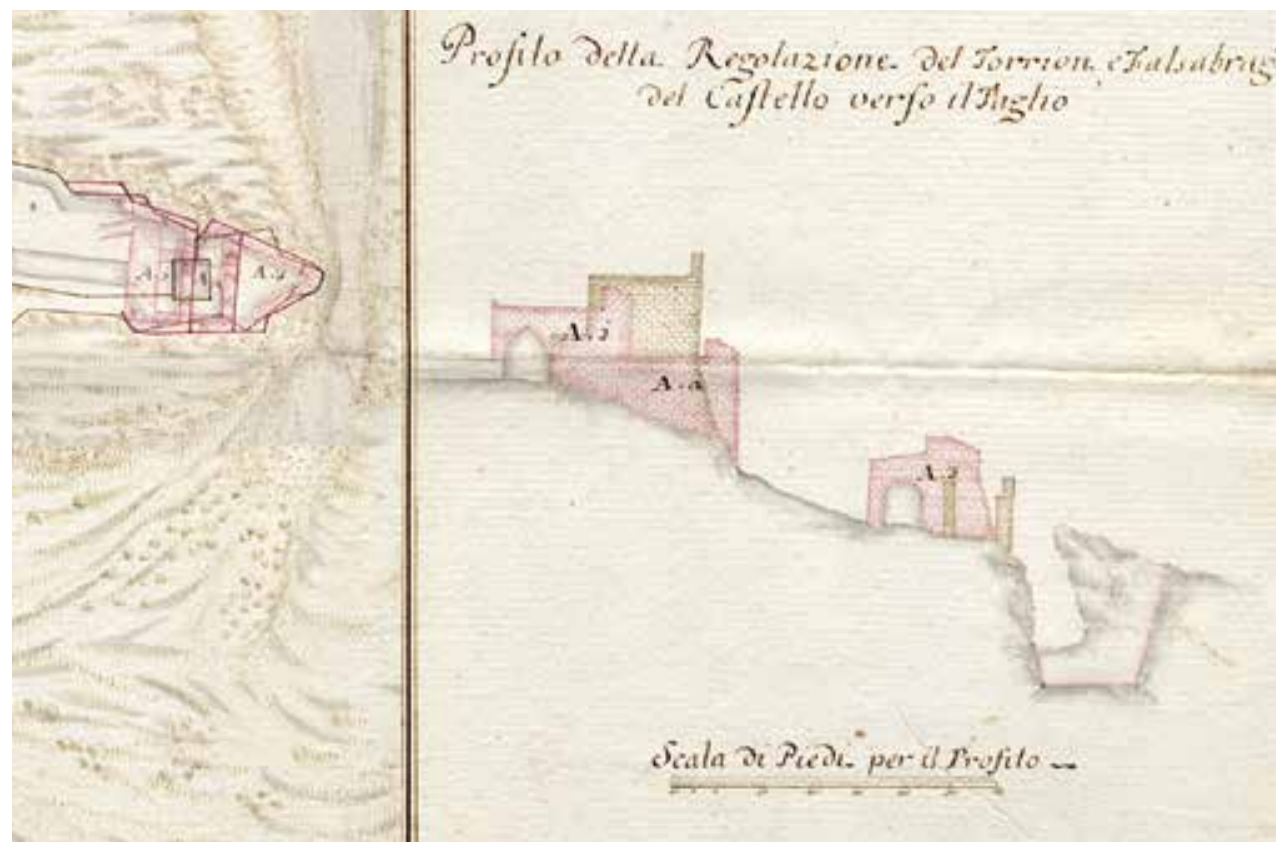

9a. Stare i nove strukture, sjeverni završetak tvrđave, detalj

Old and new structures, northern end of the fortress, detail

Međutim, prema zapisima inženjera Camozzinija, ona je već bila izgrađena početkom 1714. godine. A cijelom njegovu opisu onoga što je izgrađeno u Kninu prethodi navod da je zahvat izveden prema Jančićevu projektu; ${ }^{37}$ drugi projektanti se ne spominju. Za sjeverni završetak Kaštela Camozzini navodi da sada ima obranu u tri reda/etaže: najniži i najizbočeniji zvan Sperone, na crtežu i modelu označen s A3, potom bateriju A2, koja ima tri topovska otvora prema platou Spasa, tj. prema sjeveru, a po jedan na zapad i na istok, naposljetku gornju bateriju Al s jednakim rasporedom otvora te još jednim usmjerenim prema Loredanovim vratima. Kako je vidljivo iz citata izvornika, ${ }^{38}$ Camozzinijev opis te građevine znatno je iscrpniji od naših sažetih podataka; to vrijedi i za nastavak u kojemu Camozzini opisuje sve ostalo novo što je izgrađeno na tvrđavi od 1711. do 1714. godine, među ostalim i Jančićeve bastione. Iz strukture njegova izvješća može se, dakle, zaključiti da je sve opisano rezultat Jančićeva projekta. To bi ujedno značilo da je Jančić nakon prvotnog projekta s tlocrtom, koje smo komentirali, ubrzo dopunio taj projekt novom strukturom na sjevernom završetku, a koja je bila odmah i izvedena.

Kao indirektnu potvrdu tome pogledajmo tlocrt inženjera Avesanija, nastao zasigurno ubrzo nakon toga, čiji naslov govori da mu je svrha prikaz novih kninskih utvrda. ${ }^{39}$ Prije svega, sada nalazimo jasno prikazanu novu topovsku bateriju na sjevernom vrhu, označenu jednako kao što je opisuje i Camozzini: A3, A2, A1. Osim tlocrtno, ta je situacija prikazana i u presjeku, pa se vidi koje su dotadašnje strukture uklonjene, odnosno snižene, poput starije kule. Avesani u tlocrtu cijele tvrđave simultano donosi zatečene zidane strukture, označene crno, i one novoizgrađene, izvedene crveno, naznačujući tako koliko je opsežna bila recentna modernizacija (sl. 9, 9a). Pri tome sve nove strukture tretira jednako jer sve potječu iz kratkog razdoblja od nekoliko godina, praktično iz jedne kampanje. Zato tu nisu prikazani samo bastioni na jugoistoku ili baterija na sjeveru, već i postaja Sv. Cecilija južno uz Kaštel, potom novoformirani Korlat, modernizirana tzv. Rochetta u podnožju uz Krku, zatim novi sklop Belveder, naposljetku novouspostavljena postaja Suedese. Da su sve te strukture nastale do početka 1714 . godine svjedoči i Camozzinijev vrlo potanki opis. $U$ njemu ne nalazimo samo zapis o svakome topovskom otvoru, svakome zidu i svakoj zgradi, već i pojedinosti o načinu gradnje i dimenzijama zidova, a takve je podatke mogao navesti upravo netko tko je bio upravitelj radova na gradilištu. Tako Camozzini zapisuje gotovo svagdje da bedemi imaju skarpu, a debljina im je pri dnu iznosila primjerice $4-5$ stopa (na Korlatu) ili 7 stopa (u drugom obzidu). Svjedočio je time da je bila riječ dakako o novim, bastionskim strukturama.

Na ovome je mjestu potrebno podsjetiti na onodobnu važnost Knina za Mletačku Republiku. Jančić svoje izvješće završava patetičnom, no mogli bismo reći i konvencionalnom ocjenom Knina kao najvažnije (il maggiore) utvrde Dalmacije, a koja pak predstavlja ulaz u Jadran, predziđe Italije i zaštitu Venecije. ${ }^{40}$ No iste 1710 . godine Knin je bio smatran prvorazrednom mletačkom tvrđavom, po važnosti ravan utvrdama poput Verone, Zadra ili Krfa. ${ }^{41}$ Stoga ne iznenađuje da je bio pokrenut program opsežne modernizacije ove tvrđave, i to mnogo zahtjevniji od zahvata koji su se odvijali nakon 1688. godine. Dekret o tome donesen je u Senatu 16. 4. 1710. godine. ${ }^{42}$ Tom su prilikom navedene činjenice o Jančićevu obilasku Knina i prijedlozima koje je izložio. Rečeno je da buduće radove trebaju voditi inženjer Camozzini i satnik Falet, pod nadzorom (soprintendenza) generala Spara (Sparrèa). ${ }^{43}$ Faleta, koji se očigledno s Jančićem bio vratio u Veneciju, valjalo je uputiti natrag u Knin. Senat 


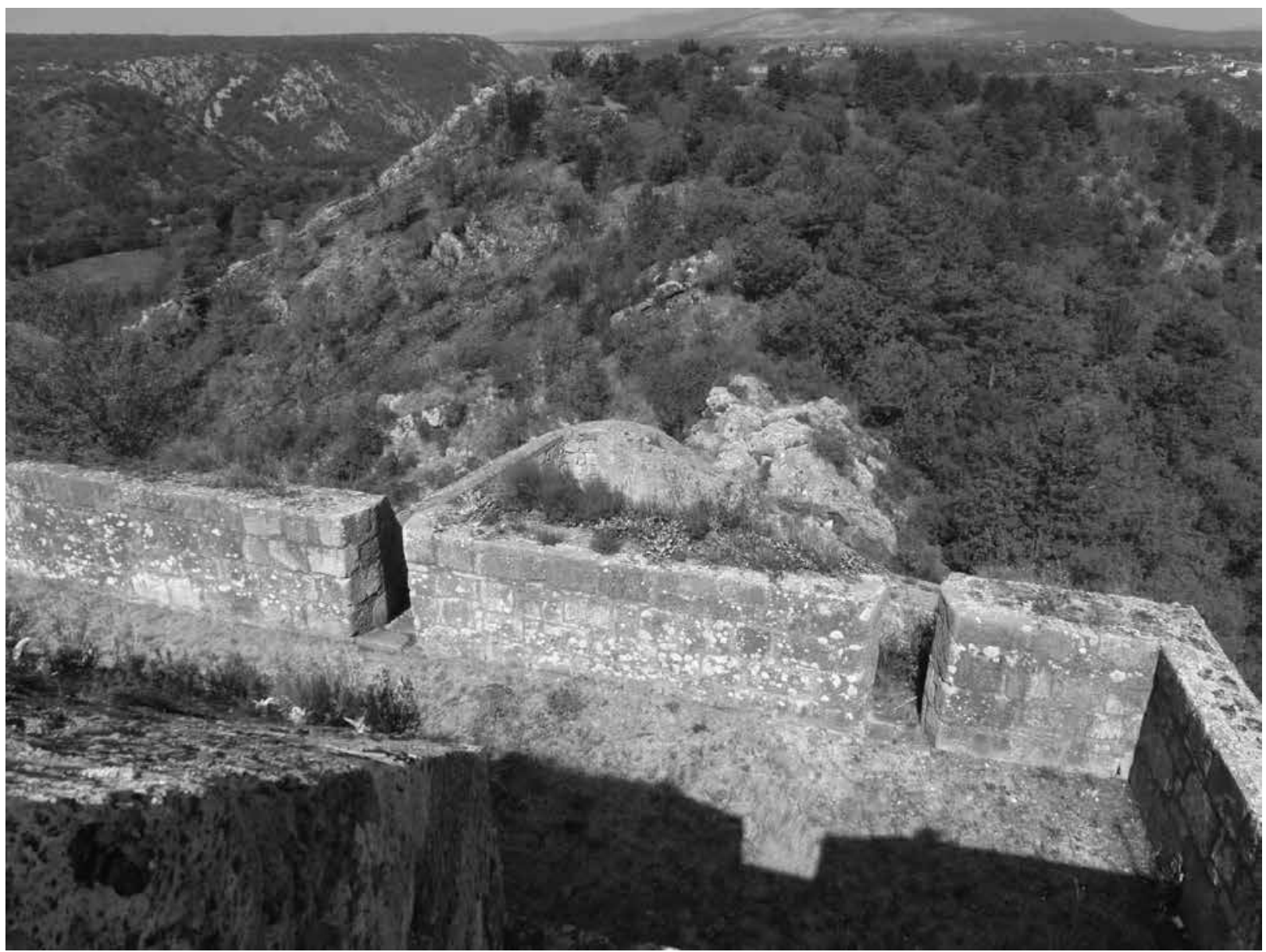

10. Baterija i sperone, sjeverni završetak tvrđave

Battery and sperone, northern end of the fortress

traži da bude osigurana svota od 17000 dukata, na koliko je Jančić bio procijenio trošak za prioritetna gornja dva obzida.

Sve u vezi s kninskom tvrđavom imalo je status žurnosti, pa se ubrzo otpočelo s radovima. U lipnju 1710. godine zapisao je dalmatinski providur da se odabiru majstori (stručni radnici) te se doprema materijal svih vrsta. ${ }^{44} \mathrm{U}$ isto doba Senat najavljuje da će pozorno pratiti napredak radova ${ }^{45} \mathrm{U}$ prvoj sezoni, tijekom 1710. godine, izvedeni su brojni radovi koji su morali prethoditi podizanju novih zidova. Tako je poravnato ili uklonjeno stijenje, iskopani su temelji, pripremljeni kameni blokovi za lice zida, dopremljeno drvo, priređene vapnenice. U izvješćima je riječ među ostalim o secondo recinto ili nuovo recinto, pri čemu je zasigurno posrijedi bilo preuređenje bedema na jugoistoku, koji je imao dobiti novu, bastionsku strukturu. Čitamo da su za to većim dijelom iskopani temelji u stjenovitom terenu. ${ }^{46}$ Spominju se radovi i na brojnim drugim mjestima kompleksa: pripremljen je teren za gradnju barutane, započet posao na kuli kraj Krke, proširivao se jarak pred sjevernim vrhom. Bili su to sve radovi još za Vincenza Vendramina, koji je dalmatinskim generalnim providurom bio do travnja 1711. godine. Njegov nasljednik Carlo Pisani provest će onda glavninu radova modernizacije i dati podići gotovo sve nove zidane strukture. Tijekom te druge sezone na gradilištu je 300 radnika svih vrsta ${ }^{47}$ te su najvažniji dijelovi bili sazidani. U 1712. godini stoga se konstatira da je tvrđava blizu tome da preuzme funkciju te se traže topovi za njezino opremanje. ${ }^{48}$

O dovršetku tvrđave više je puta riječ 1713 . godine, primjerice u travnju, kolovozu odnosno listopadu, studenome. ${ }^{49} \mathrm{Da}$ je Senat savjesno pratio modernizaciju vidljivo je po modelima tvrđave koji su bili upućivani u Veneciju, primjerice početkom 1713. godine, ${ }^{50}$ te onda godinu dana kasnije, kada je Camozzini izradio dva modela: stanja prije zahvata te izgleda tvrđave s novim strukturama. ${ }^{51}$ Providur Pisani se s pravom ponosio svojim učinkom u izgradnji tvrđave - jer je u njegovu razdoblju izvedena glavnina radova - pa ipak je ponešto prenaglašavao svoje zasluge u odnosu na prethodnika Vendramina.

Vidjeli smo da su radovi bili započeti prema Jančićevu projektu 1710. godine, no neosporivo je da je taj projekt u idućim godinama bio dopunjen još nizom struktura. O tome Pisani piše barem na dva mjesta: u lipnju 1713. navodi da su prvotne zamisli doživjele brojne važne dopune, ${ }^{52} \mathrm{a} \mathrm{u}$ veljači 1714. godine podjednako svjedoči da nisu primijenjeni samo prijedlozi iz prvog projekta, već i mnogi drugi. ${ }^{53}$ Jasno je na temelju dosad iznesenih podataka da je bastionski sklop na jugoistoku (bastioni Pisani i Vendramin) Jančićevo rješenje, kao i sklop Belveder na jugu, a iz Pisanijevih i Camozzinijevih zapisa dalo bi se zaključiti da je on bio autorom i ostalih brojnih struktura izvedenih u Pisanijevo doba, ${ }^{54}$ među kojima i troetažne baterije na sjevernom završetku. 


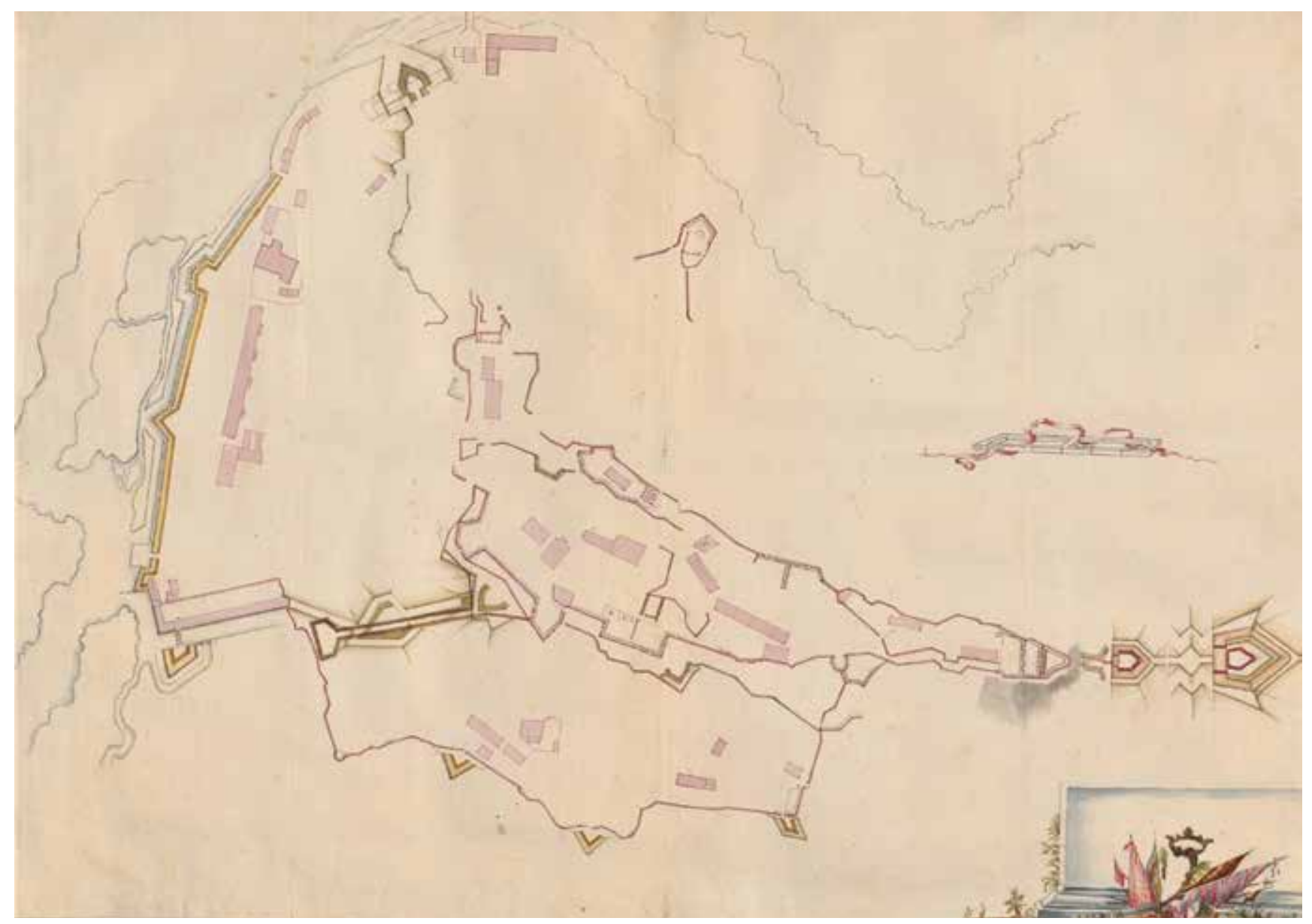

11. Projekt dogradnje kninske tvrđave (Württembergische Landesbibliothek, Stuttgart)

Extension project for the Knin Fortress

\section{Podatci do kraja stoljeća}

Nakon tog doba intenzivne modernizacije nije na tvrđavi bilo većih dogradnji i preinaka. Pogledajmo stoga još nekoliko podataka o Kninu tijekom 18. stoljeća, napose neke kritičke komentare, kojih je, kao i kod drugih utvrda, također bilo. Providura Pisanija naslijedio je Angelo Emo, u čije su doba na tvrđavi izvedene zanemarive intervencije. $\mathrm{O}$ tome govori tlocrt u kojemu su različitim bojama označene stare strukture (primjerice Candia nuova), potom ono što je izgrađeno $\mathrm{u}$ doba Pisanija (gotovo sve strukture tvrđave) i napokon ono što potječe iz Emova mandata, a to je tek određeno pojačanje sjevernoga vrha i dvije omanje platforme u južnom dijelu Kaštela. ${ }^{55}$

Kninska je tvrđava zbog svoga statusa i svoga strateškog položaja ostala u središtu zanimanja mletačkih dužnosnika i stručnjaka. Unatoč njezine recentne modernizacije bit će u idućim desetljećima primjedaba i prijedloga za pojačanje njezinih obrambenih mogućnosti, a izrađivani su i projekti u obliku tlocrta. Jedan takav nedavno smo otkrili u Stuttgartu, a zbog toga što je zapravo nedovršen, tj. izostali su bilo kakvi natpisi ili oznake, ostao je neprepoznat te zagubljen među dokumentacijom Krfa. ${ }^{56}$ Tlocrt donosi tvrđavu približno u stanju nakon Pisanijevih zahvata, no ne može se zaključiti iz kojeg doba 18. stoljeća prikaz potječe. Na sjevernoj strani prikazano je proširenje utvrde na nasuprotni plato, u obliku originalno oblikovanog elementa nalik dvostrukoj fleši. Najmarkantnije rješenje pak predviđeno je na jugoistoku, podno Jančićeve bastionske strukture: ondje vidimo ponovo flešu i simultano prikazan element nalik nekom koridoru. Je li to alternativno rješenje ili - vjerojatnije - podzemni hodnik, nemoguće je znati bez dodatnog tumačenja. Vidimo osim toga predviđena pojačanja na donjem obzidu, tj. utvrdama naselja, koje početkom stoljeća nisu bile modernizirane poput gornjih obzida. Tu je bio zamišljen nov bedem prema rijeci, a mjestimice i zaštite pojedinih točaka elementima nalik na raveline (sl. 11).

Posebno zanimljiv dokument je opis Dalmacije iz pera generala Spara, upućen Johannu Matthiasu von der Schulenburgu, glavnom zapovjedniku mletačke vojske. ${ }^{57}$ Taj je tekst mogao biti potpora Schulenburgovu posljednjem izviješću o Dalmaciji, iz 1732. godine; ${ }^{58}$ premda Sparov tekst nije datiran, iz nekih navoda moglo bi se zaključiti da potječe iz doba oko 1731. godine.$^{59}$ Njegov osvrt na Knin osobito je relevantan jer je upravo on bio superintendant radova dvadesetak godina ranije, prema tome je odličan poznavatelj tvrđave, a sada uza sve to identificira pojedine njezine nedostatke. Predložio je modernizaciju strukture Candia nuova i 
njezino povezivanje s kavalirom Suedese, preuređenje prilaza obzidu Belveder, te izgradnju neke utvrde na nasuprotnom platou prema sjeveru, što je bila tema koja je zaokupljala stručnjake još od Alberghettijeva doba. Spar potom nabraja na kojim su još mjestima potrebne vojarne (quartieri), a koje postojeće valja popraviti. Njegova cjelovita analiza nije dakako mimoišla onu krucijalnu infrastrukturu: barutane i cisterne. Ističe da kninsku barutanu treba dopuniti barem još jednom, jer ako jedina barutana strada, može to zapečatiti sudbinu tvrđave ${ }^{60}$ Podjednako su važne cisterne, kojih su postojale tri, a Spar vidi potrebu i za četvrtom cisternom. ${ }^{61}$

Spomenut ćemo još nekoliko relevantnih vojnih stručnjaka koji su sredinom stoljeća procjenjivali vrijednost kninske tvrđave. Među njima je važan general William Graeme, zapovjednik mletačke kopnene vojske. On je 1757. godine boravio u Kninu te je sačuvana njegova bilježnica s komentarima tvrđave na engleskom, ${ }^{62}$ a godinu potom nalazimo osvrt na Knin u sklopu njegova izvješća o Dalmaciji. ${ }^{63} \mathrm{U}$ prvom tekstu popis nedostataka kninske tvrđave je dulji, a njegov ton oštriji, prelazeći katkad i u ironiju. Graeme se nije pokazao zagovornikom predbedema (falsabraga), pa tako niti ovih kninskih, tvrdeći da su preslabi, a odviše izloženi neprijatelju. Važan predmet njegove kritike su i odviše visoki i slabi zidovi, poneki i s kruništem. ${ }^{64}$ No i ondje gdje su smještene topovske baterije parapeti su, smatra, odviše visoki i slabi.

No službeno izviješće iz 1758. godine dosta se razlikuje od zapisa u bilježnici. Vrijedna su načelna razmatranja o utvrdama na uzvisinama koja vrijede uz Knin, piše Graeme, i za druge dalmatinske utvrde. Izdvojit ćemo njegovo zapažanje o loše reguliranom pristupu ulazu u drugi obzid u bastionu Pisani kninske tvrđave. Taj je bastion, smatra general, odviše visok, pa topovi s njega ne mogu učinkovito nadzirati uspon prema njemu iz pravca Loredanovih vrata. ${ }^{65}$

No središnja tema Graemeova osvrta je sjeverni završetak Kaštela, a time i cijele tvrđave. To je najkritičnija točka, jer joj se nasuprot nalazi opasni plato, zapravo nastavak uzvisine Spas (Graeme ga zabunom na jednome mjestu zove Spaar!). ${ }^{66}$ Sjeverni završetak utvrde, smatra pisac, najslabiji joj je dio, ali i onaj što ga je najteže osigurati. Ondje postavljeni topovi, na speroneu i dvije baterije nad njim, ne bi se mogle nositi s topovima koje je moguće rasporediti nasuprot. Osim toga, visina građevina u sklopu Kaštela čini ih ugroženima, a s njih pak topovima nije moguće dobro nadzirati niži nasuprotni plato. ${ }^{67}$ I uza sve to, Graeme tvrdi da je Knin najvažnija utvrda Dalmacije te da se isplati uložiti u njegovu obnovu. ${ }^{68}$

Uz iscrpne analize dvojice vojnih stručnjaka, spomenut ćemo još nekolicinu osvrta, poput onoga Rossinijeva iz 1755. godine. Navodi potrebne popravke, a sklop uz bastion Pisani komentira riječima: quel moderno recinto ${ }^{69}$ Francesco Rossini bio je nazočan u Kninu još 1714 . godine, a poslije se povremeno vraćao, predlažući poboljšanja. Tako je zabilježeno da je 1753. preuzeo nadzor nad dalmatinskim utvrdama, za koje su bili predviđeni daljnji zahvati. ${ }^{70}$ To nas podsjeća kako je Venecija i dalje predviđala novi mogući rat s Turcima, ne mogavši znati da ga više neće biti. U takvim strateškim promišljanjima kninska je tvrđava sigurno imala jednu od glavnih uloga.

Daljnja izvješća i ocjene Knina postoje zatim iz doba oko 1787. godine; ${ }^{71}$ napokon, navodimo i Zavoreov kritički osvrt iz 1797., godine pada Mletačke Republike. ${ }^{72}$

Pregled brojnih dostupnih podataka o kninskoj tvrđavi, i napose nekoliko povijesnih tlocrta, pokazao je da se posve jasno može kazati kada je tvrđava promijenila svoje lice iz srednjovjekovno-turske u novovjekovnu bastionsku utvrdu: to se zbilo u četiri građevinske sezone od 1710. do 1713 . godine. Pritom su glavne uloge odigrali, svaki na svoj način, inženjer Jančić i providur Pisani. Jančićev udio u novim strukturama nije do kraja jasan; neosporivo mu se pripisuje sklop dvaju bastiona na jugoistoku te sklop Belveder, a vjerojatno su uz njegovo ime vezane i druge nove strukture iz tog doba. Svakako je Jančić zaslužio više spomena no što je to bio slučaj kod ranijih autora o kninskoj tvrđavi (Fisković, Bezić), koji su pisali više o Macanovićima nego o Jančiću, stvarnom autoru Knina. Valjda je to stoga što o njemu nisu imali daljnjih podataka. ${ }^{73} \mathrm{U}$ njegovo je doba, dakle, Knin i građevinski postao ono za što je slovio - prvorazredna tvrđava, a takvim je ostao i cijelo 18. stoljeće.

\section{Bilješke}

1

Ovaj je rad izrađen u sklopu projekta Instituta za povijest umjetnosti Graditeljska baština jadranske Hrvatske u ranom novom vijeku i pisani povijesni izvori (PU-IPU-2019-3).

2

Iz tog doba potječe, primjerice, izvještaj mletačkog inženjera Vincenza Benaglija, koji zaključuje da bi bilo teško opskrbljivati utvrdu toliko udaljenu od mora, rizično bi bilo opremiti je topovima i streljivom jer prijeti opasnost od gubitka i, napokon, da utvrda znači više štete nego koristi; Biblioteca del Museo Correr, Venecija (dalje: BMCVe), Morosini-Grimani, 540 (20. 8. 1648.).

3

Dobar prikaz povijesnog razvoja kninske utvrde: PETAR ŽIVKOVIĆ, Oblikovanje kninske tvrđave i grada do godine 1918., u: Stjepan Antoljak - Trpimir Macan - Dragutin Pavličević (ur.), Kninski zbornik, Zagreb, 1993., 96-122.

4

Biblioteca Nazionale Marciana, Venecija (dalje: BNMVe), ms. It. VII 94 (10051), fol. 10. Orazio Alberghetti bio je pripadnik poznate mletačke inženjerske obitelji (od šestorice braće najvažniji su Giusto Emilio i Sigismondo). Orazio je umro 1689. na Peloponezu; Dizionario biografico degli Italiani, I, Roma, 1960. 628-630; DARKA BILIĆ, Inženjeri u službi Mletačke Republike. Inženjeri i civilna arhitektura u 18. stoljeću u mletačkoj Dalmaciji i Albaniji, Split, 2013., 141.

5

Alberghettijev prikaz iscrpno opisuje BOSILJKA BEZIĆ, Prilog poznavanju kninske tvrđave, u: Fiskovićev zbornik II, Prilozi po- 
vijesti umjetnosti u Dalmaciji, 22 (1980.), 137-150. O prikazima Knina vidjeti također: Knin. Kninska tvrđava. Konzervatorski elaborat, Hrvatski restauratorski zavod, Zagreb, 2018.

6 BMCVe, P.D.c. 581, 296r (22. 11. 1693.). I ovaj autor, poput Benaglija, upozorava da je Knin odvojen i udaljen od mora: od Šibenika 40 milja, od Splita 60, od Trogira 50, a od Zadra 80 milja.

7

DARKA BILIĆ (bilj. 4), 164-167.

8

Archivio di Stato, Venecija (dalje: ASVe), Collegio, Relazioni finali di ambasciatori e pubblici rappresentanti, 68.

9

"Piazza di gran consequenza, e n'hanno l'occhio sopra non meno i Cesarei, che i Turchi.»

10

BMCVe, Morosini-Grimani, 495, Notta delli ripari più necessarii alle fortezze poste fra terra nelle provincie di Dalmatia et Albania; dokument nije datiran, ali potječe iz razdoblja između 1704. i 1708. godine.

11

Kaštel i Korlat dvije su starije jezgre na hrptu kninske uzvisine: Kaštel na sjeveru, Korlat na jugu.

12

Kriegsarchiv, Beč, Karten- und Plansammlung (dalje: KA), K VII i $2 \alpha$.

13

"Si sono ristorate in [?] luoghi le mura, li depositi, i quartieri, e le abitazioni del Rappresentante e del Governatore, accomodate le vecchie cisterne, ed escavata una nuova nel forte superiore.«

14

"La piazza è della maggior importanza (...) per la sua situatione, nella presente consistenza non può negassi molto debole $\mathrm{e}$ diffetosa.

15

ASVe, Provveditori da terra e da mar e altre cariche (dalje: PTM), filza 550 (busta 376): »...la pubblica providenza mi ha prescritto di far formar et assogetarle il disegno di quella di Knin con i suoi bisogni...«, 9. 7. 1708.

16

ASVe, PTM, f. 550, 1. 12. 1708.

17

ASVe, Provveditori alle fortezze, dis. 97.

18

U legendi stoji: »Il color verde dimostra le nuove propositioni per meglio assicurare la piazza«.

19

"...si farà un altra piatta forma congionta alla porta del secondo recinto per armare due pezzi di canone per impedir li assalti verso la porta Loredana e dall'altra parte della sudetta piattaforma si tirerà un recinto di muro con suo terrapieno, continuando sino al piedi del grebano del Corlatta...«

20

"...si farà la piatta forma più grande apresso il torione sopra il volto nella porta di sortita nella falsa braga del castelo la qual piatta forma sarà fatta per armar tre pezzi di canone...«
21

BMCVe, Cl. XLIVb n. 790.

22

Compendio delli proggietti stabiliti di concerto tra li ingigneri d'Andre e Camozzini. Inženjer Giovanni Battista Camozzini djelovao je u Dalmaciji od 1706. godine, JOŠKO KOVAČIĆ, Mjernik i graditelj Giovanni Battista Camozzini, Kulturna baština, 24-25 (1994.), 86

23

»Piataforma da farsi per difesa del secondo recinto, e della Porta Loredana."

24

»Si fara un volto sopra l'andito che va nella falsa braga, et terapienare il sitto no. 3 sino a livello della somità del detto volto, e poi sbassare il torion B facendo una piazza per tre pezzi di canoni.«

25

»Torion sul quale si può maneggiare un sol falconetto.«

26

ASVe, PTM, f. 551 (b. 377).

27

"...sargente general Janxich, con commissione d'essaminar occularmente l'idea concepita dall'ingegnere sudetto [D'Andre], e di soggettar ciò, che trovasse più accomodato alla migliore diffesa e sicurezza di posto si importante. «; ASVe, Senato, Deliberazioni, Rettori. Registri, 85.

28

Biblioteca Fondazione Querini Stampalia, Venecija (dalje: QS), ms. 154, 19.3. 1710.: »Pervenuto a Knin, la mia prima applicatione fu d'esaminare la piazza nel tratto di cadauno de suoi recinti, con la scorta del dissegno dell'ingegner Andrees. Persuaso però questo, sopra luoco, di qualche diffetto del suo dissegno, non meno, che del suo progetto, e calcoli, ho dovuto valermi dell'opera assidua del capitan Fallet, et ingegner Camuccin, per rillevar intieramente una pianta più essata della piazza, con i profili necessarii alla formatione d'un adequato progetto, e dei più giusti calcoli..."

29

ANDREJ ŽMEGAČ, Mletački graditelj utvrda Antun Jančić, Radovi Instituta za povijest umjetnosti, 37 (2013.), 103-105.

30

BMCVe, Cl. XLIVb n. 504.

31

"Atteso però le accennate molte mancanze, ho creduto del mio riverentissimo zelo, e debito humiliar a Vostra Serenità, in due progetti, l'idea universale della fortificatione, che può ridur la piazza nella sua più giusta, e adequata diffesa, proportionata al grande oggetto, per cui si considera."

32

Navodi da je dotadašnje čuvanje baruta zbog pokrova nesigurno: »La polvere si conserva sopra una torre (E) del castello, coperta di soli coppi, col grave rischio, e facile, di qualche accidente, e d'essere guastata anche dalla pioggia.«

33

»Vi considero possibili due attachi; l'uno nel latto rimarcato (...) secondo recinto, perduto che fosse l'inferiore, o città bassa; l'altro all'angusta fronte, che viene presentata dal castello verso l'eminenza, che li rimane al di fuori." 
34

Relatione dell'Acquisto dell'Importante Piazza di Knin in Dalmatia..., Venetia, 1688.

35

»In oppositione al primo, propongo tutta quella difesa, che può essere [?] permessa dalla situatione, e dall'arte, ritirando il recinto in [?] figura fiancheggiata (1.3.4), e riducendo parte del presente ristretto muro in falsabraga (2.2.2); così che possa rader e scoprir meglio la pendenza del monte. Le faccie (3.3) de i due piccioli bastioni, prive di falsabraga, restano situate sopra grebbani di non mediocre altezza; con che, per attaccar quella parte del regolato recinto, bisognarebbe neccessariamente superar la falsabraga, e mettersi fra due fuochi."

36

"Fatto questo, conviene ridur quella falsabraga (21) in miglior consistenza, e solidità, proportionata a resister a qualche pezzo d'artiglieria, che potesse esserli opposto sul monte, che li rimane fuori, et in forma, che possa contraporsene due o tre pezzi. Vi propongo pure dei volti, per tenere, in si ristretto luoco, i diffensori, a coperto, e dalle bombe, e dalle pietre da mortaro, e dalloffese dei rissalti delle pietre della torre più interna, bersagliata che fosse. Possono questi volti servir anco di riccetto a matteriali, e viveri; da questi si communica con una sortita, o porta di soccorso, che propongo verso la parte occidentale di quella falsabraga. La torre (B) del castello, coll'abbassamento di qualche piede della altezza, si riduce in un piano eguale a quello del breve latto contiguo, e si dilata la larghezza del loro ramparo, in forma che possa contener due pezzi di cannone, in oppositione all'eminenza, e da potersi rivoglier anco ai latti.«

37

»Sotto il General Vincenzo Vendramino sui proggetti del sargente general Giansix fu deliberato dall'Eccellentissimo Senato di riedificar, e fortificar nella miglior forma e struttura la sudetta piazza."

38

»In castello si e fortificata la parte settentrionale disposta in tre ordini di diffesa, cioe il più basso et avanzato chiamato il sperone segnato nel modello, e dissegno A3 fabricato con mura a scarpa grossa 7 in 8 piedi nella base, l'interno del muro nella parte più esposta, è tutto de tuffi grandi quanto poteva portare un cavallo, dentro di detto muro si è fatto un volto longo passi 19 in 20 , largo 4 in 6 piedi, con porta di sortita per comunicare nel taglio, e sul monte Spas, sopra, questo volto vi e la strada coperta. (...) La battaria segnata A2, con 3 canoniere batte di fronte il monte Spas, et altra canoniera da ponente che batte verso la Promina, la rochetta, et il ponte di Porta Molina, cosi altra canoniera da levante che batte la campagna, et il borgo, con un volto sotto la stessa battaria verso ponente che ha la comunicatione alla strada coperta del sperone sopranominato con altra troniera inarbata che batte il ponte e la rochetta, et un'altro volto che comunica in castello, qual passa sotto la battaria superiore. Questa battaria superiore segnata $A 1$ ha sei canoniere, 3 battono di fronte il monte Spas, una da ponente altra da levante, et altra che batte per schena la Porta Loredana, sotto detta piazza, o battaria oltre il volto che comunica con la battaria $\mathrm{A} 2$ vi sono altri due volti che servono per tenire [?] li letti de canoni, et altro, con altro volto longo che comunica con il sperone segnato A3«; Muzej hvarske baštine, Hvar (dalje: MHB), Arhiv Bučić, XXIII/1, siječanj 1713. m. v., tj. siječanj 1714 .

39

BMCVe, Ravà Fenton, 4327, Dissegno della fortezza di Knin con le nuove fortificazioni. Xaverio Avesani bio je Jančićev učenik. Nazočan je na kninskom gradilištu već u doba prije rata, a u siječnju 1716. bio je imenovan i za javnog inženjera u Dalmaciji; DARKA BILIĆ (bilj. 4), 147, 282; BMCVe, Cicogna, 2941/II/23.

40

"...considerata nelle sue vere consequenze è il maggior propugnaculo di tutta la Dalmatia, la quale è porta [?] del Golfo, antemurale dell'Italia, e diffesa dell'istessa città Dominante.«

41 ASVe, Savio alla Scrittura, 179.

42 ASVe, PTM, f. 553 (b. 378), 10. 7. 1711.

43

"...tutto havera a farsi sotto la direttione dell'ingegner Camozzini, e del capitan Falet, con la sopraintendenza del sargente general Spar...«; MHB, Arhiv Bučić, Bučić F, VIII.

44

"...si va in tutta diligenza sciegliendo maestranze et ammassando materiali d’ogni genere...«; ASVe, PTM, f. 551, 19. 6. 1710.

45

"...intention del Senato l'accurata nostra vigilanza al più sollecito travaglio delle decretate fortificationi di Knin«; ASVe, Senato, Deliberazioni, Rettori, 160, 18. 6. 1711.

46

"...fondamenta per la regolazione del secondo recinto escavate su terreno grebbanoso per due tercine...«; ASVe, PTM, f. 552 (b. 378), 1. 3. 1711 .

47

Camozzini bilježi da su radnici stigli odasvud, s područja od Kvarnera do Korčule. Spominje Ivana i Ignacija Macanovića kao prote. Postojali su i posebni proti tesara i kovača.

48

ASVe, PTM, f. 553, 13. 5. 1712.

49

"...le cose sono ridotte quasi all'intiero della lor perfettione...«: ASVe, PTM, f. 554 (b. 379), 20. 4. 1713.; "...nel vicino ottobre, saranno, sul piede del primo progetto, compiti li suoi lavori...«: isto, 23. 8. 1713.; "Ridotta quella piazza al compimento de suoi vasti, importantissimi lavori...«: isto, 20. 11. 1713.

50

»...il modello della piazza medesima [Knin], che metterà sotto l'occhio lo stato, in cui fù, e quello, in cui si attrova in presente, con la distintione di cadaun de suoi importantissimi, vasti lavori, che ebbero principio colla mia carica...«: ASVe, PTM, f. 554, 11. 1. 1712. m. v., tj. 1713.

51 ASVe, PTM, f. 554, 25. 2. 1713. m. v., tj. 1714.; MHB, Arhiv Bučić, Bučić XXIII/1.

52

"...caderà sotto l'occhio il modello della piazza, in cui sarà facile essaminare la quantità, e qualità delle nuove fabriche, e se saranno state regolate nelle misure delle prime idee, anco con multiplici importanti aggiunte...«: ASVe, PTM, f. 554, 20. 6. 1713.

53

"...non solo tutte quelle proposte dal primo progetto, ma altre ancora, molte in numero, e rimarcabili in qualità...«: ASVe, PTM, f. 554, 25. 2. 1713. m. v.; u istom dokumentu i ova tvrdnja: »... piazza di Knin, redenta et elevata (...) sopra i plausibili progetti del sargente general Jansich...» 
54

Tome ne proturječi niti Schulenburgov zapis: »...quella di Knin come alle nove fabriche in essa proposte dal generale Giansix tutte costrutte sotto la directione del detto ingegnere Camuzini..." (MHB, Arhiv Bučić, Bučić F, X).

55

Hrvatski državni arhiv, Zagreb, Kartografska zbirka, K VII i 97. U označavanju bojom učinjene su i neke greške: ljubičastom bojom za starije strukture označeni su i topovski otvori na Korlatu, a propušteno je tako označiti stariji rondel Topanu.

56

Württembergische Landesbibliothek, Stuttgart, Sammlung Nicolai, sv. 104, 16r.

57

Copia di scrittura del tenente general baron Sparrè presentata a Sua Eccellenza marascial Conte di Scolemburg nell'occasion del suo pasagio per la provintia della Dalmatia alla Dominante, QS, ms. 154.

58

ANDREJ ŽMEGAČ, Schulenburg's defence of Dalmatia, Archivio Veneto, VI serie, 18 (2019.), 108.

59

"Li superiori recinti d'essa furono, vent'anni sono ristaurati di pianta ma non del resto [?] perfezionati«.

60

»Un solo accidente che accade nell'unico deposito, decide senza riparo del destino della piazza.«

61

"Tre sono in fine le cisterne che rachiude, capaci di sette in otto mille barilla d'aqua, oltre le quali sarebbe utilissimo consiglio construirne un altra..."

62

Notes in English of Dalmatia and Albania. Annotazioni sulla Dalmazia. 1757. Scritte di proprio pugno dal Generale Greeme al servizio Della Repubblica Veneta; BNMVe, ms. It. VII 1934 (9060).

63

Relazione delle Provinzie della Dalmazia \& Albania, del Signore Tenente General Greme; KA, K VII i 6F.

64

"...but what is most surprising in all the new works and reparations of Knin is to see the walls that are oposd to the enemys cannon so thin reasd so high there parapets yet higher and all crenelé...«(114).
65

"...questa è anche la parte per cui ascendesi con una strada dal borgo situato al piedi del monte sino alla porta del castello. La quale strada in molti luochi è coperta alla vista del ramparo da molte vecchie muraglie, e case, quali possono servire d'alloggiamento all'inimico, e facilitare l'ascesa al castello, in luoco che dovrebbesi procurare possibilmente \& scoprire il pendio del monte. Non vi è fosso con ponte levatore, o altropera da superare per arrivare alla porta; si marchia di piede franco sino ad essa, ed il fianco del bastion Pisani nel quale è situata, non può rasare la sudetta strada ch'ad essa conduce, essendo troppo alto."

66

»Erzessi questa nella sommità di un monte, la parte più accessibile del quale, e opposta ad una collina nominata Spaar, dalaquale fù battuto il castello allorche fù preso..."

67

„Questa parte non solo è la più debole del castello di Knin, ma la più dificile ad esser fortificata. Molto incomodareramente al castello è la parte S. Salvatore che fuori del recinto, la quale se bene di ristretta fronte, rassomigliando ad una racchetta, con il manico rivolto allo spirone, s'allarga pocco addietro in maniera che aggevolmente piantar vi si può una batteria di 10, a 12 pezzi di canone, la quale certamente prevalerebbe allo spirone, ed alle due batterie sopra esso..."

68

"Egl’è certo però ch'anche nello stato suo presente essa è la miglior piazza della Dalmazia, ed il dinaro speso nella sua riparazione fù bene impiegato, ed ecconomizato.«

69

KA, Inl. C III Knin 1, 10v.

70

ASVe, Savio alla Scrittura, 216: »...ritornò in Dalmazia a sostenere con particolare inspezione la sola sopraintendenza principale de' lavori decretati nelle piazze di quelle provincie..."

71

QS, ms. 154 .

72

KA, Inl. C III Knin 2, 17. 8. 1797. Njegove primjedbe tiču se, među ostalom, nedostatne sigurnosti glavnog ulaza u bastionu Pisani te troetažne baterije na sjevernom završetku tvrđave.

73

Jančić je spomenut u radu CVITO FISKOVIĆ, Ignacije Macanović i njegov krug, Prilozi povijesti umjetnosti u Dalmaciji, 9 (1955.), 214. Bezić Jančića niti ne spominje, ali zato navodi Macanoviće, Kazotija i Cicindelu; BOSILJKA BEZIĆ (bilj. 5), 150. 


\section{Summary}

\section{Andrej Žmegač \\ Modernization of the Knin Fortress in the $18^{\text {th }}$ Century}

The Knin Fortress played an important role in the late period of the Venetian Republic. Venice had conquered the Turkish fortress in 1688, during the Morean War. After that, minor works were done on its modernization, intensifying around 1708. It is at that time (1710) that Knin was included in the Venetian fortifications of the first order, along with some key fortresses such as Verona, Zadar, or Corfu.

The main construction works took place in 1710-1713 according to the project of the Venetian engineer Antun Jančić (Antonio Giancix in the Venetian sources). Undoubtedly, the new belt in the southeast (two bastions, one of which contains the entrance, and the so-called falsabraga) and the Belvedere complex in the south should be attributed to him. His original project from 1710 was supplemented by various additions and extensions, most likely his work as well. The construction works started at the time when Vincenzo
Vendramin was the Provveditore Generale of Dalmatia, but took place mainly under Provveditore Carlo Pisani; the supervisor of the works was General Spar (Sparrè) and the administrator engineer Camozzini.

Knin remained an important fortress throughout the $18^{\text {th }}$ century, as Venice calculated that there would still be some warfare with the Turks. As a result, projects to strengthen it were still being made from time to time, such as the hitherto unknown project from Württembergische Landesbibliothek in Stuttgart. There were also numerous comments by Venetian military experts, who mostly criticized the high and weak walls, as well as the set at the northern end of the fortress, insufficiently strong to withstand a massive artillery attack from the north.

Keywords: fortress, bastion, Venetian Republic, Knin, Antun Jančić 